\title{
Mineralogical and petrographical studies of agricultural soil, Assiut Governorate, Egypt
}

\author{
E. A. Abou El-Anwar *iD, H. S. Mekky, S. A. Salman, A. A. Elnazer, W. Abdel Wahab and A. S. Asmoay
}

\begin{abstract}
Background: The lack of information about the Egyptian soil needs more attention, especially mineralogical, petrographical studies, and quality data. Thus, the aim of this study was to evaluate the physicochemical parameters of north Assiut agricultural soil; $\mathrm{pH}$, moisture\%, $\mathrm{CaCO}_{3} \%$, organic matter (OM\%), and mineralogical contents of the studied soil.

Results: The studied soil is characterized by alkaline nature, low organic matter, and high $\mathrm{CaCO}_{3} \%$. Mineralogically, the studied agricultural soil samples consist mainly of quartz, plagioclase, and minor calcite (as non-clay minerals), as well as montmorillonite, vermiculite, and illite in decreasing abundance order as clay minerals. The plagioclase consists of two minerals; calcined albite and anorthite.

Conclusion: The clay minerals in the studied soils may be derived from the old alluvial plain (Plio-Pleistocene sediments) by successive Nile floods and reworking. The recorded clay minerals in the studied soils are montmorillonite, vermiculite, and illite in decreasing order of abundance. They have the ability to retain the irrigation water and adsorb more exchangeable cations in aqueous media which can feed the plants.
\end{abstract}

Keywords: Mineralogy, Agricultural soil, Petrography, Assiut, Organic matter, Egypt

\section{Introduction}

The soil constituents are inorganic minerals and organic matter of different size and composition. The particles account for about $50 \%$ of the soil's constituents. Pores may contain air and/or water represented the remaining volume (Jensen 2000). The particle size distribution (PSD) of soil is one of the most basic physical attributes due to its great effect on the other soil properties related to water faction, productivity, and soil erosion (Gimtnez et al. 1997; Montero 2005). The rate and extent of many physical and chemical reactions, including the sorption and desorption of elements, are controlled by soil texture. Montero (2005) determines the amount of surface on which the reactions can take place. Therefore, PSD can control the level of metal concentrations in soil. Fine particles $(<60 \mu \mathrm{m})$ are more reactive and have a higher surface area than coarser material (WHO 1982; Lin et al. 1998).

Mineralogical constituents (especially clay minerals), $\mathrm{pH}$, moisture $\%, \mathrm{CaCO}_{3} \%$, and organic matter $(\mathrm{OM} \%)$ govern the productivity of soil (Salman: Geochemical and environmental studies on the territories west River, unpublished; Deshmukh and Aher 2014). Asmoay (2017) pointed out the prevailing of montmorillonite and kaolinite in the studied soils of Sohag and El Minya. Clay minerals are so important to evaluate the magnitude of soil fertility (Miller and Donahue 1992).

The soil of Nile Valley resulted from fluvial processes, which mainly covers $3.5 \%$ of the total Egyptian lands. It is compact when dry and swell when wet, due to the nature of the clay minerals epically montmorillonite. Thus, the clay minerals can keep water molecules with many soluble ions required for plants. There is lack in assessment of the Egyptian soil requirements.

Thus, the aim of this study was to assess the petrographical and mineralogical characteristics of the north Assiut District agricultural soil. Furthermore, the source of the soil is the way to improve their nature. Mineralogical and petrographical studies were carried out on the collected soil samples.

* Correspondence: abouelanwar2004@yahoo.com

Geological Sciences Department, National Research Centre (NRC), 33 El

Bohouth St. (former El Tahrir St.), Dokki, POB 12622, Giza, Egypt 


\section{Materials and methods}

\section{The study area}

Assiut Governorate is located between latitudes $26^{\circ} 50^{\prime}$ and $27^{\circ} 40^{\prime} \mathrm{N}$ and longitudes $30^{\circ} 40^{\prime}$ and $31^{\circ} 32^{\prime} \mathrm{E}$ and the cultivated land extends along the two banks of the River Nile (Fig. 1). It comprises part of the Nile Valley and parts of the surrounding plateaus. Assiut Governorate contains many big industries, such as cement, chemical fertilizers, detergents, and food. The study area includes mainly the relatively wide stretch extending to the west of the Nile River.

Many authors studied geology (Fig. 2) and structural geology of the area (Said 1962 and 1981; Omara 1972 and Youssef et al. 1977; Omer 1996; Osman 1980; Shaker: Geoelectrical and hydrogeological studies on the area northwest of Assiut between Bani Adi and Mir, Nile Valley, Egypt, unpublished; Khalifa et al. 2004). The present area is distinguished into the following three main geomorphic units:

- The young alluvial plain (Holocene silty clay): it is occupied by the cultivated lands bordering the western side of the Nile. It is dissected by irrigation canals and drains running from south to north parallel to the River Nile. The Nile tends to occupy the eastern side of its valley in Assiut area so that the cultivated lands to the west of the river are generally much wider than those lands to the east.

- The old alluvial plain (Quaternary sand and gravel): It occupies the slope area between the calcareous plateau and the young alluvial plain west of the River Nile. It is represented by terraces with various elevations above the young alluvial plain. The surface of the concerned units is occupied, besides the old terraces, by elongated sand dunes. The old terraces cover a considerable area and formed mainly of travertine conglomerate with gravel, sandstone, and clay. While the sand dunes cover extreme eastern areas of the scarp of the carbonate plateau. It takes mainly the northwestsoutheast direction and threats the cultivated lands of the present alluvial plains.

- The calcareous plateau: the eastern slope of the western calcareous plateau in the area of study represents the western fringes of the Nile Valley. It has an elevation higher than floodplain varies from south to the north. It is built up of Eocene limestone covered by drift sands, flints, and boulders of carbonate. Dark brown to black gravelly plains are occupying areas in the surface.

\section{Sampling and analyses}

Sixteen soil samples (30 cm depth) were collected around the industrial activities in the study area, which is represented the young alluvial plain (Fig. 1). The global positioning system was used for locating the sampling points. The mineral composition of the investigated soil is recognized by X-ray diffraction analysis and petrographical investigation. Mineralogically, selected six samples were investigated by the X-ray diffraction technique at the Egyptian Mineral

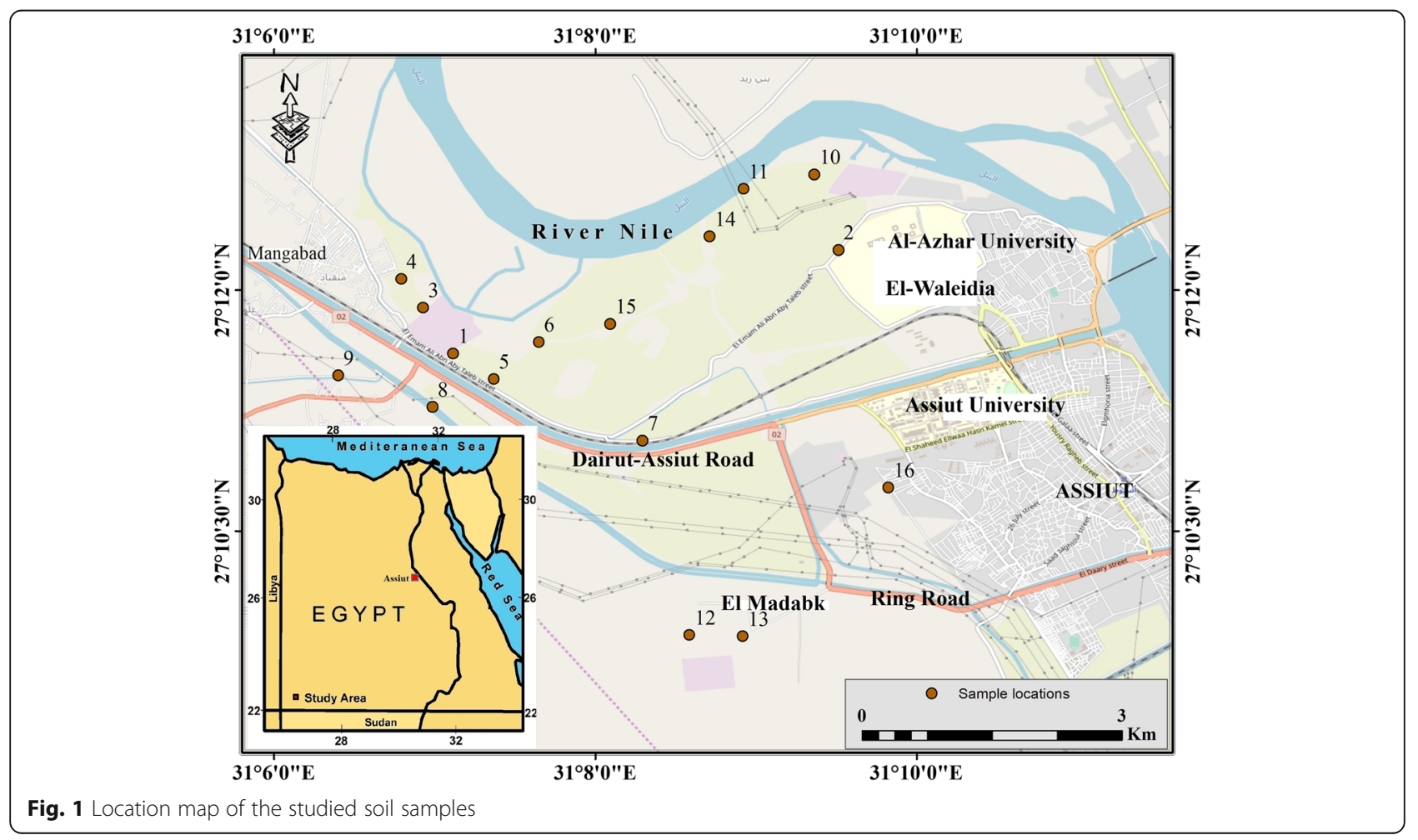




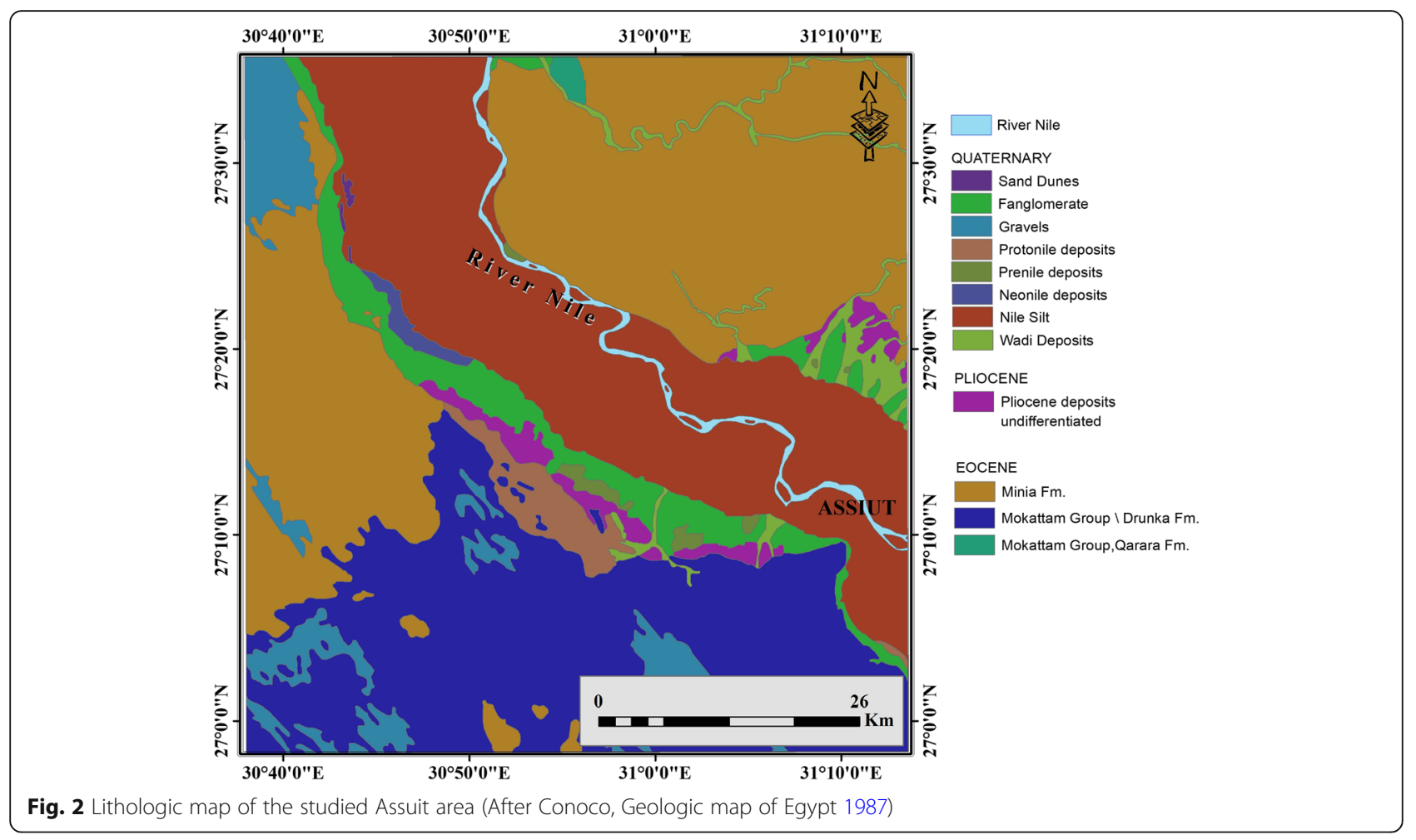

Resources Authority (Dokki, Egypt) using a PANalytical $\mathrm{X}$-Ray diffraction equipment model X'Pert PRO with Secondary Monochromator, Cu-radiation $(\lambda=1.542 \AA)$ at $45 \mathrm{kV}$, $35 \mathrm{~mA}$, and scanning speed $0.02^{\circ} / \mathrm{s}$ were used. The morphology and the size of the synthesized samples were characterized via scanning electron microscopy (SEM) coupled with energy-dispersive spectroscopy EDS (SEM Model Quanta FEG 250) in the National Research Center laboratories. The reference data for the interpretation of the X-ray diffraction patterns were obtained from the X-ray powder data file index (Smith 1961) in addition to the ASTM, X-ray diffraction card file (Poppe et al. 2001).

\section{Results}

Values of the physical parameters showed that soil $\mathrm{pH}$, moisture, OM, sand, silt, and clay average contents were $7.63,3.5 \%, 2.4 \%, 39.2 \%, 33.9 \%$, and $26.6 \%$; respectively (Table 1 ). The close difference between the mean and the median of the studied parameters indicted the unique factor controlling these parameters distribution.

X-ray diffractometry (Fig. 3) revealed that the studied agricultural soil samples consist mainly of quartz (65.05\%), clay minerals (16.99\%), plagioclase $(17.31 \%)$, and minor calcite $(0.65 \%)$. The clay minerals are composed of montmorillonite (10.8\%), vermiculite (4\%), and illite (1\%) in decreasing order of abundance (Fig. 4). The plagioclase consists of two minerals; calcine albite (15.4\%) and anorthite (0.7\%). Also, the SEM examination of the soils samples showing montmorillonite (Figs. 5 and 6), which is confirmed with the XRD results. In polarizing microscopic examination, other less abundant minerals, such as amphiboles (3.6\%), magnetite and hematite $(4.4 \%)$, pyroxene $(2.5 \%)$, garnet $(1.6 \%)$, epidote $(0.8 \%)$, and apatite $(0.5 \%)$ of total sample matrix, were detected (Figs. 7, 8, 9, 10, 11, and 12).

Table 1 Descriptive statistics of the physicochemical characteristics of the studied soils

\begin{tabular}{llllllll}
\hline & Moisture\% & $\mathrm{pH}$ & Sand\% & Silt\% & Clay\% & $\mathrm{OM}^{2}$ & $\mathrm{CaCO}_{3} \%$ \\
\hline Mean & 3.5 & 7.63 & 39.2 & 33.9 & 26.6 & 2.4 & 9.0 \\
Median & 2.9 & 7.68 & 32.7 & 37.3 & 27.5 & 2.4 & 7.3 \\
Standard deviation & 2.7 & 0.31 & 25.9 & 19.5 & 7.1 & 0.7 & 8.8 \\
Minimum & 0.6 & 6.91 & 6.3 & 2.8 & 16.0 & 1.0 & 0.5 \\
Maximum & 9.3 & 8.12 & 82.5 & 61.8 & 35.0 & 3.5 & 34.0 \\
\hline
\end{tabular}



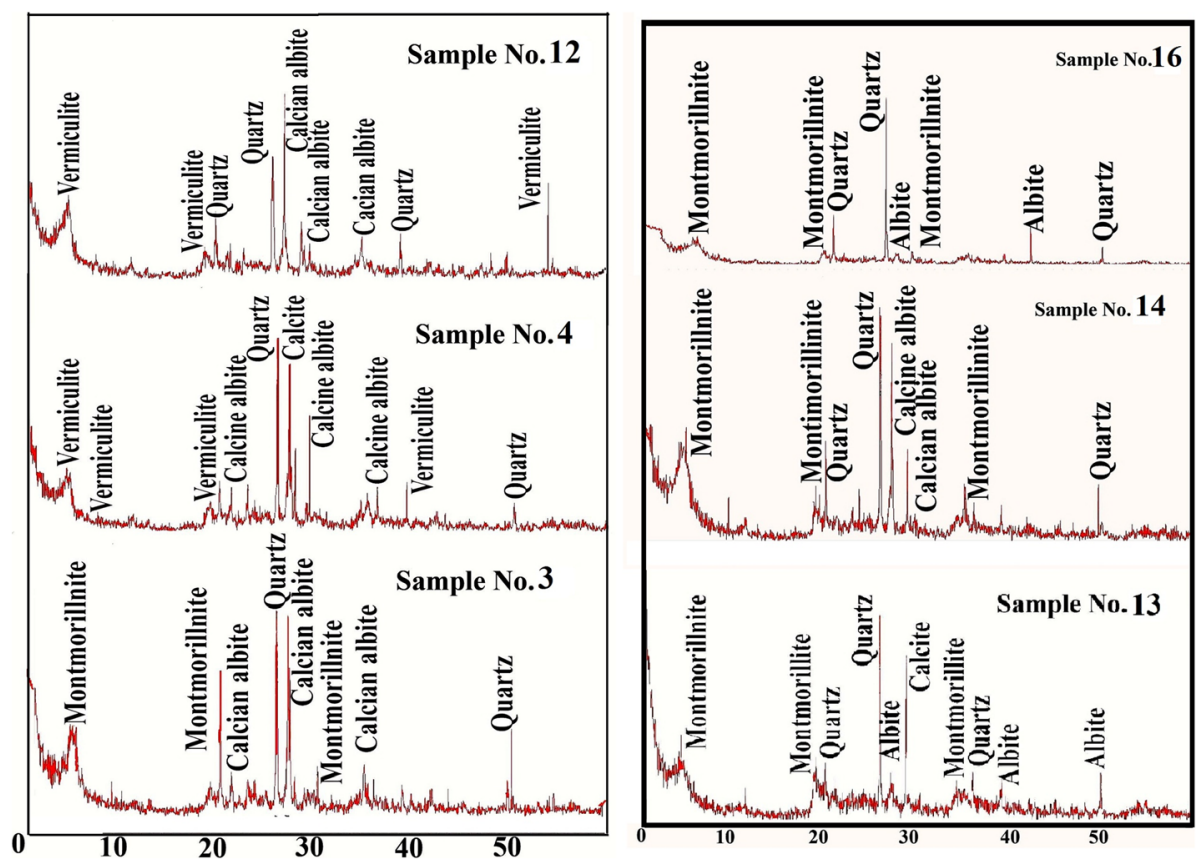

Fig. 3 X-ray diffraction results of Assiut soil samples

\section{Discussion}

\section{Physicochemical properties}

Sand and silt constitute the skeleton of the soil body, whereas clays constitute the reactive fraction of the soil (Hillel 2004). The comparison of the current results with other parts of the Nile valley (Table 2) indicated a little variation in the studied physicochemical properties of soil. This variation may result from the location, agricultural practices, and industrial activities. According to Folk (1974) triangle

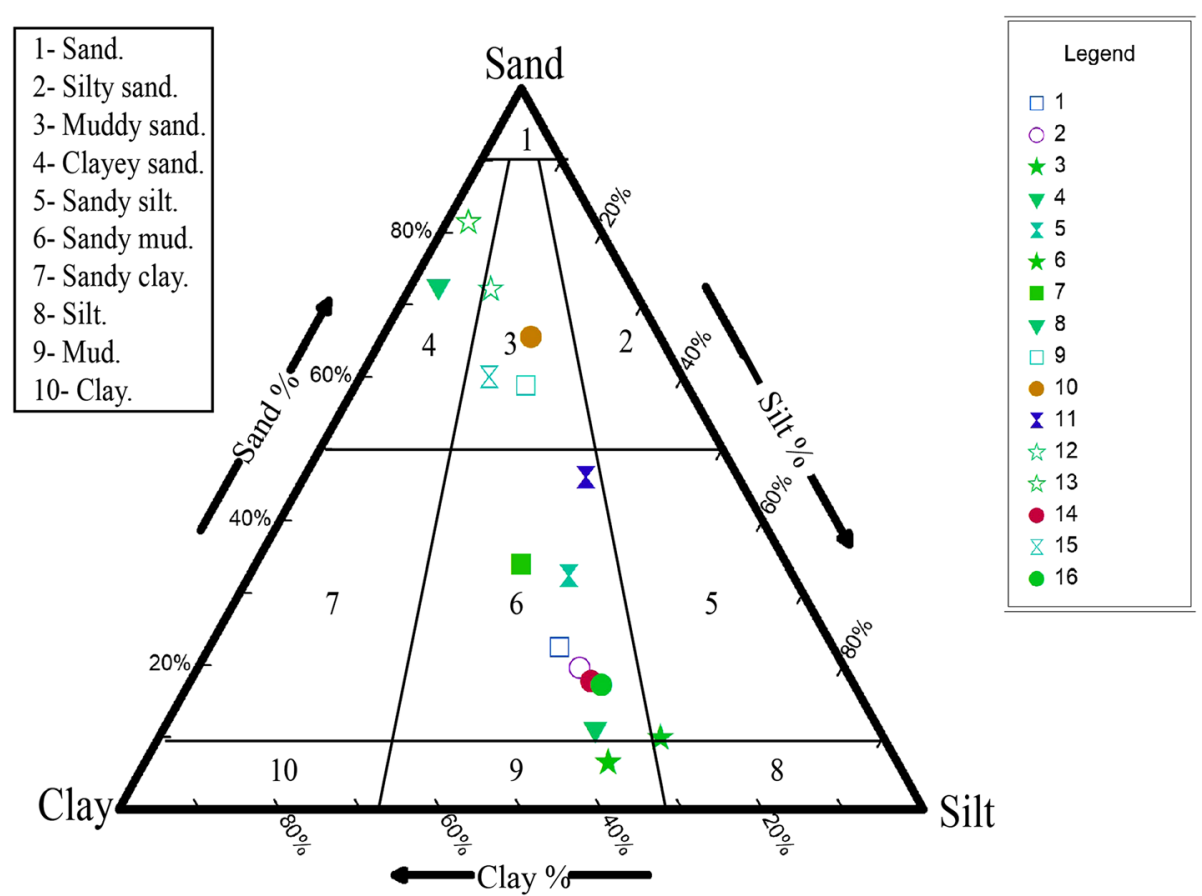

Fig. 4 Folk triangle diagram of soil classification 


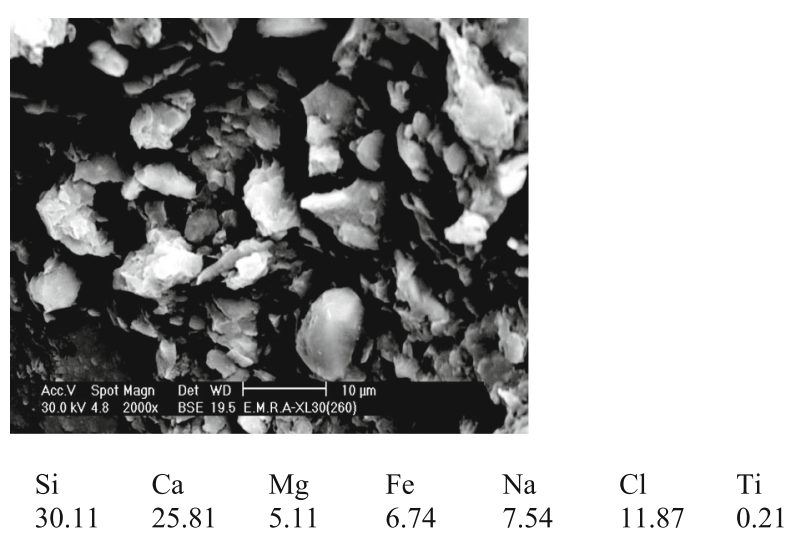

Fig. 5 SEM photomicrograph showing authigenic and detrital montmorillonite with ragged illite flakes, with face to face orientation (montmorillonite occurs as wavy sheets)

(Fig. 4), the studied soil samples can be texturally classified into three groups; sandy mud (eight samples) muddy sand (four samples), clayey sand (two samples), sandy silt (one sample), and mud (one sample).

PSD represents the most significant soil physical and even some soil chemical properties (Centeri et al. 2015). It is the most vital characteristic affecting pore geometry, porosity, pore size distribution, solid surface area, hydrophysical, and thermo-physical characteristics (Cartacuzencu et al. 2014; Mady and Shein 2017).

PSD influence some factors such as moisture retention and transmission properties; coarse-textured soils have low moisture retention and high permeability. Whereas fine-textured soils have high moisture retention and low permeability. This may be indicated from the correlation between sand and moisture (Table 3). The soils with high clay content will have low permeability (Deshmukh and Aher 2014). The clay fraction contains more alumina and has a higher content of humus. Therefore, the properties of soils are affected by clay content rather than silt and sand particles. Thus, the authors thought that the most important factors affecting the chemical properties of soils in the study area referred to the higher proportion of the clay content. Because the fine particles have a larger surface area and hence be more reactive than coarser fractions (WHO 1982; Lin et al. 1998).

The results of the present study show that the topsoil layer of the study area exhibits a wide variation of $\mathrm{CaCO}_{3}$ content, ranging from 0.5 to $34 \%$ (Table 1). The studied soils are considered calcareous soil because it contains more than $5 \% \mathrm{CaCO}_{3}$. These results were in agreement with the XRD which showed the presence of calcite (Fig. 3). Only samples (5 and 11) contain an anomalous value of $\mathrm{CaCO}_{3}$; these two samples are closed to the electric power station and fertilizer factory respectively. This indicates that the factors influencing the $\mathrm{CaCO}_{3}$ distribution are aridity, carbonate deposits, and human activity. Lime precipitates in the soil due to limited leaching may be resulting from two processes; low rainfall/high evapotranspiration or restricting subsoil layers and associated saturated conditions (Netterber 1978; Driessen and Deckers 2001). The distribution and amount of carbonates influence soil fertility. The increase of calcium carbonate in soil was led to a considerable decrease in the availability of most nutrients (Chein and Somponges 1987). Where carbonate minerals cause immobilization of metals by providing an adsorbing and nucleating surface (Hassan 2015).

The studied soil samples OM flocculated between 1 and $3.5 \%$ (Table 1). The results indicate that the study area soil contains low amount of OM. Loveland (2003) suggested that the major OM threshold in temperate regions is $3.4 \%$, below which potentially serious decline in soil quality will occur. Accordingly, the quality of soil in the study area is under stress because the studied samples have less than 3.4\% OM. The deficiency of OM

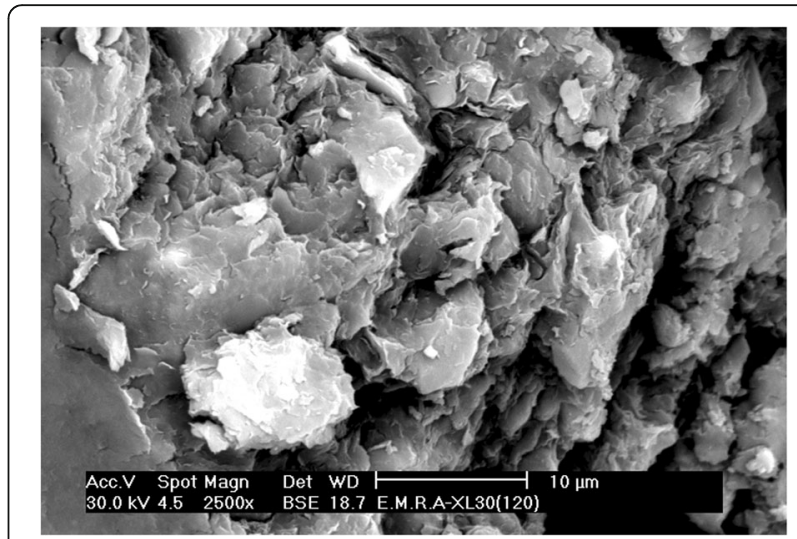

Fig. 6 SEM photomicrograph illustrating montmorillonite with relatively well-crystallized illite. Note that montomorillonite occurs as wavy sheets 


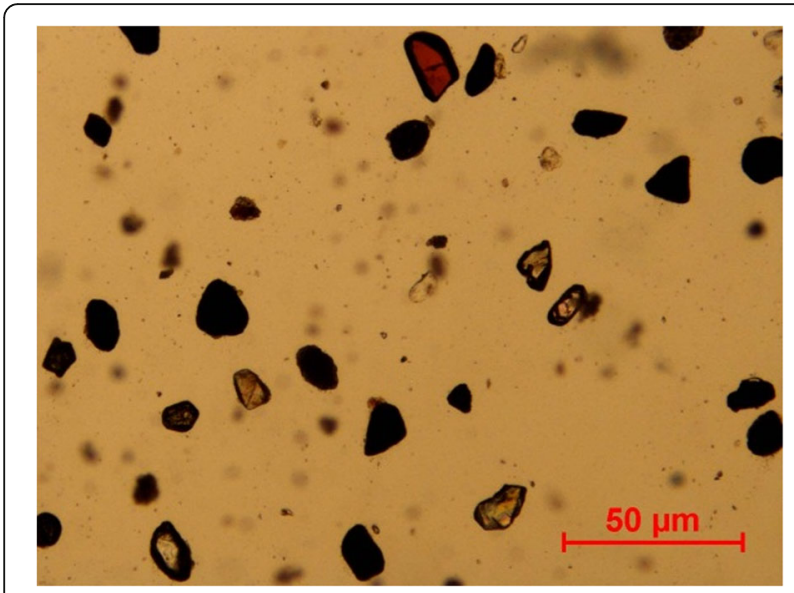

Fig. 7 Heavy fraction composed of opaque's (black), zircon (zoned colorless euhedral to subhedral grains), and staurolite (reddish brown at the upper part of photo), heavy fraction, PPL. $\times 40$

could indicate that negligible amount of organic matter is added to soil in the form of crop residues and manure (Khan 1984). The aridity of the area and hot summer temperature could also lead to the degradation of $\mathrm{OM}$ (Tamhan et al. 1964). Also, it was found that tillage operation disrupts soil structure and accentuates soil organic matter oxidation by increasing aeration, which stimulates microbial activity. Soils under cultivation using irrigation and tillage generate optimal conditions for decomposition of OM (Quiroga et al. 1998; Ortega et al. 2002).

\section{Mineralogical study}

X-ray diffraction patterns (Fig. 3) revealed that the clay minerals content is low relative to the sand (quartz \%), but they play an important role in supplying the

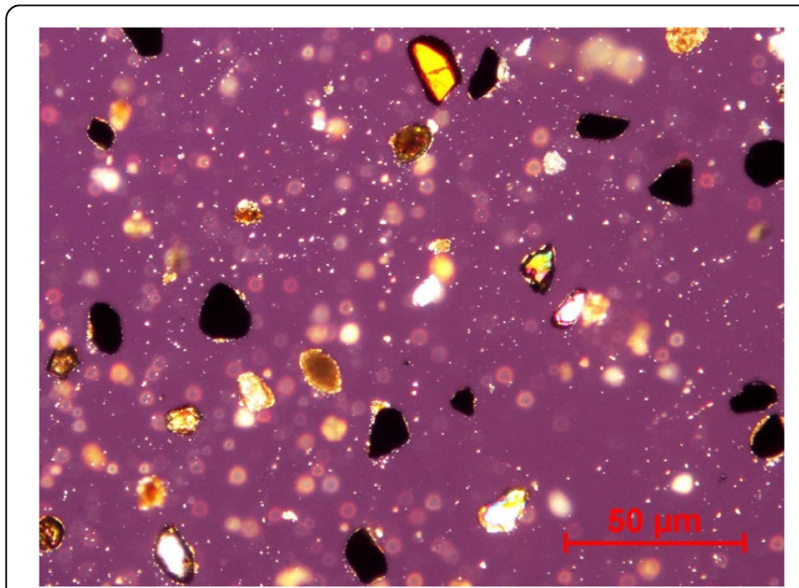

Fig. 8 Heavy fraction composed of opaque's (isotropic), zircon (exhibits zoning and green, yellow, or upper part), heavy fraction, C.N. $\times 40$

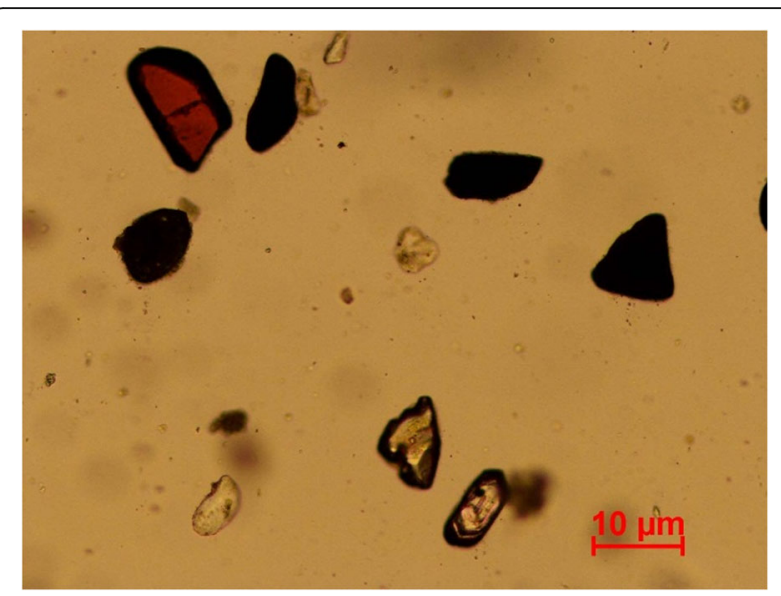

Fig. 9 Heavy fraction composed of opaque's (black), zircon (zoned colorless euhedral to subhedral grains), and staurolite (reddish brown at the upper left corner), heavy fraction, PPL. $\times 100$

exchangeable cations, which required for plant nutrition. The investigated clay minerals display no specific pattern of distribution in the studied area. The semi-quantitative estimation showed obviously that there is general similarity in the common proportions of the clay minerals in the investigated samples. Thus, it is strongly suggested the origin of soil from a common parent sedimentary and metamorphic rocks. There is an abundance of clay minerals; montmorillonite and vermiculite are more than illite mineral. The southern sector is characterized by vermiculite and illite minerals. Therefore, the clay minerals in the studied agricultural soil samples are derived from continental source rocks throughout the River Nile, whereas in marine mud, the amount of illite exceeds the amount of montmorillonite (Weaver 1989).

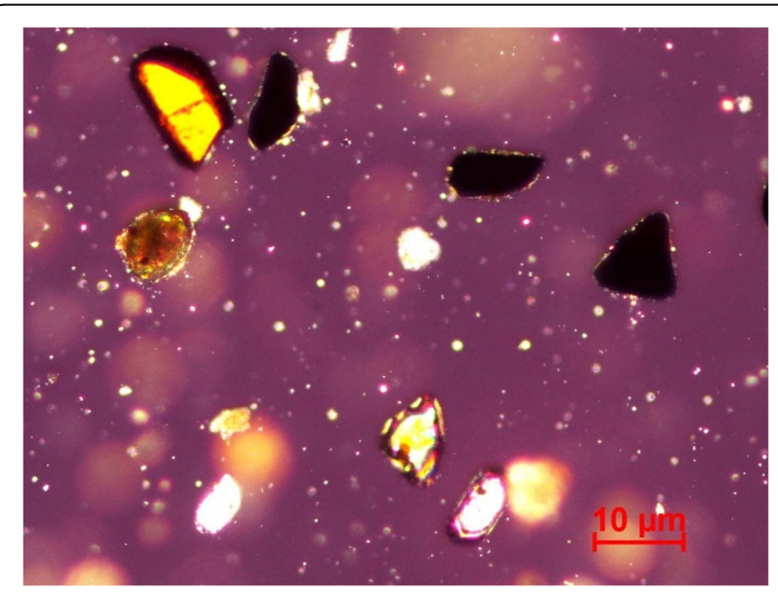

Fig. 10 Heavy fraction composed of opaque's (isotropic), zircon (exhibits zoning and green, yellow, or violet interference colors), and staurolite (exhibits golden yellow interference colors at the upper left corner), Heavy fraction, C.N. $\times 100$ 


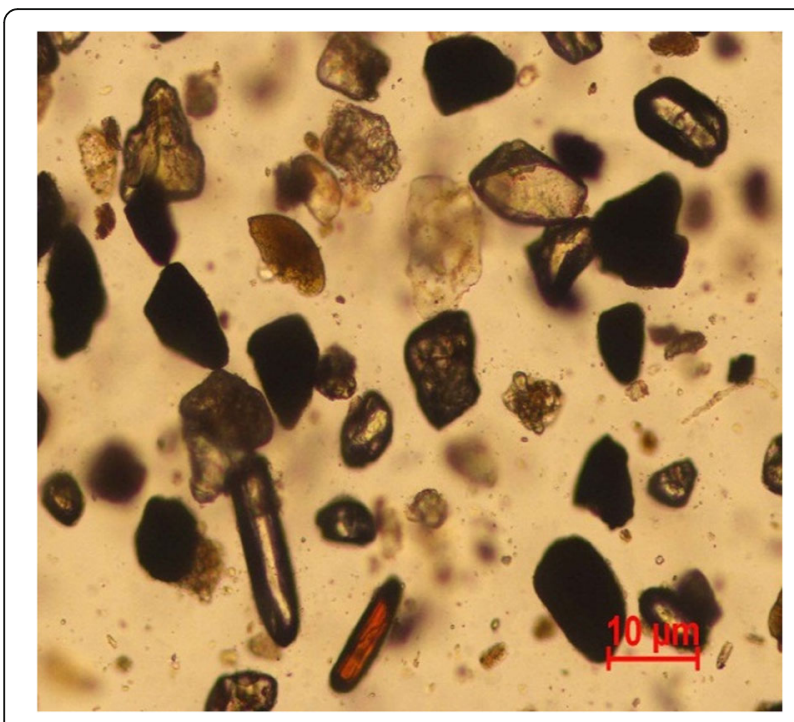

Fig. 11 Heavy fraction composed of opaque's (black), zircon (zoned colorless euhedral to subhedral grains), staurolite (reddish brown at the lower part), and epidote (pale green angular grains at the upper left corner), heavy fraction, PPL. $\times 100$

SEM examination showed that the montmorillonite occurs as a medium to fine size particles and aggregates, and well-crystallized. The composition, morphology, and crystallinity characteristics of the studied clay minerals indicate that they are detrital and authigenic origin (Abou El-Anwar 2017, 2018; Abou El-Anwar et al. 2017, 2018a, b). The abundance of montmorillonite refers to deposited under warm/humid climate (Abou El-Anwar 2018; Abou El-Anwar and Samy 2013).

Summing up the above-mentioned results, we can conclude that the encountered clay minerals assemblage in the investigated soil samples is generally detrital and

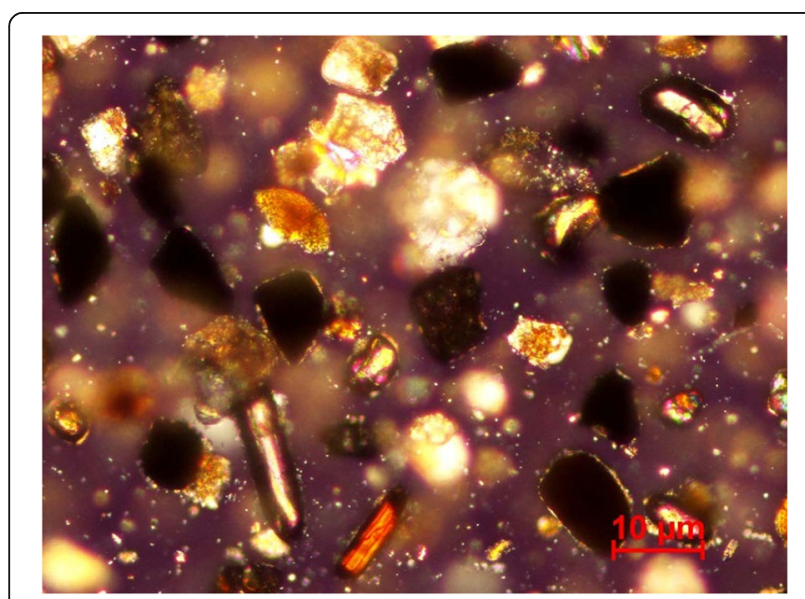

Fig. 12 Heavy fraction composed of opaque's (isotropic), zircon (exhibits zoning and green, yellow, or violet interference colors), staurolite (exhibits golden yellow interference colors at the lower part), and epidote (exhibits yellow interference colors at the upper left corner), heavy fraction, C.N. $\times 100$
Table 2 Comparison between the soil physicochemical properties in the study area and other parts of Egypt

\begin{tabular}{lllllll}
\hline & $\mathrm{pH}$ & $\mathrm{Sand} \%$ & $\mathrm{Silt} \%$ & $\mathrm{Clay} \%$ & $\mathrm{OM} \%$ & $\mathrm{CaCO}_{3} \%$ \\
\hline Current study & 7.63 & 39.2 & 33.9 & 26.6 & 2.4 & 9.0 \\
El Minya (Asmoay 2017) & 7.94 & 33.86 & 39.49 & 24.55 & 2.81 & 16.58 \\
El-Tebbin (Hassan 2015) & 7.5 & 46.6 & 37.6 & 15.1 & 4.3 & 17.4 \\
Sohag (Salman 2013) & 8.1 & 20.6 & 51.2 & 28.1 & 2.3 & 8.7 \\
\hline
\end{tabular}

authigenic in origin, mostly related and derived from Nile sediments. The drainage from the Ethiopian Highland composed mainly of basic volcanic rocks which contributed most of the mineral assemblages (cf. Abou El-Anwar and Samy 2013).

\section{Petrographical study}

The occurrence of amphiboles, magnetite, hematite, pyroxene, garnet, epidote, and apatite indicate metamorphic and intermediary or basic source rocks of soil (Omer 1996).

The microscopic investigation of the heavy mineral fractions (63 $\mu \mathrm{m}$, grain size) of some sediments of the studied area confirmed that its mineralogical composition constitutes opaque minerals. The detected non-opaque minerals are zircon, staurolite, and epidote in decreasing order of abundance. Opaque's represent the most abundant minerals in the heavy fraction. They occur as black sub-rounded to anhedral or irregular angular grains that exhibit isotropism (Figs. 7, 8, 9, 10, 11, and 12).

Zircon occurs as colorless euhedral to subhedral grains that exhibit concentric growth zones (Figs. 7, 9, and 11). It shows green, yellow, or violet third-order interference colors (Figs. 8, 10, and 12). Staurolite occurs as dark brown, reddish brown, yellowish brown, or brownish black subhedral prismatic crystals (Figs. 7, 9, and 11). It exhibits distinct pleochroism "colorless, yellow or red, golden yellow". It shows golden-yellow interference colors (Figs. 8, 10, and 12). Epidote occurs as pale green anhedral or irregular angular grains (Figs. 6, 7, 8, 9, 10, and 11). It exhibits green or yellow third-order of the interference colors (Fig. 12).

Table 3 Correlation coefficient between the physicochemical properties of the studied soils

\begin{tabular}{llllllll}
\hline & Moisture\% & $\mathrm{pH}$ & Sand\% & Silt\% & Clay\% & $\mathrm{OM} \%$ & $\mathrm{CaCO}_{3} \%$ \\
\hline Moisture\% & 1.00 & & & & & & \\
$\mathrm{pH}$ & -0.14 & 1.00 & & & & & \\
Sand\% & -0.48 & -0.19 & 1.00 & & & & \\
Silt\% & 0.51 & 0.22 & -0.98 & 1.00 & & & \\
Clay\% & 0.36 & 0.09 & -0.88 & 0.78 & 1.00 & & \\
$\mathrm{OM}_{4}$ & 0.07 & -0.45 & 0.01 & -0.04 & 0.04 & 1.00 & \\
$\mathrm{CaCO}_{3} \%$ & 0.40 & 0.16 & -0.02 & 0.09 & -0.19 & 0.00 & 1.00 \\
\hline
\end{tabular}




\section{Conclusion}

The studied agricultural soil samples minerals are quartz, clay minerals, plagioclase, pyroxene, amphiboles, biotite, garnet, and epidote and magnetic minerals. The cultivated lands in the Nile valley are predominated by sandy silt soil type. With increasing of clay fraction, the soil becomes compact, dark, high saline, alkaline, and severely swells and shrinks. With increase sand fraction, it becomes loose, yellow, or gray and highly porous and permeable. The main sources of nutrient (e.g., $\mathrm{Ca}, \mathrm{Mg}$, $\mathrm{K}, \mathrm{Fe}, \mathrm{Mn}, \mathrm{Cu}, \mathrm{Zn}, \mathrm{Ni}$ ) are plagioclase, mica, and mafic minerals, which by weathering provide the soil with a significant amount of these elements in a form available for plant nutrition.

To improve the physical properties of sandy clay soil, a significant amount of coarse-grained sand must be added. In contrast, to decrease the porosity and permeability of the sandy soil, a considerable amount of silt and clay needs to added, which occurs within the Nile terraces from the old alluvial plain.

\section{Acknowledgements}

The authors would like to thank The Geological Sciences Dept., National Research Centre for facilitates during this work

\section{Funding}

NRC internal project ID: 11080101

\section{Availability of data and materials}

Not applicable.

\section{Authors' contributions}

All authors contributed equally in all article steps. All authors read and approved the final manuscript.

\section{Ethics approval and consent to participate}

Accepted.

\section{Consent for publication}

Accepted.

\section{Competing interests}

The authors declare that they have no competing interests.

\section{Publisher's Note}

Springer Nature remains neutral with regard to jurisdictional claims in published maps and institutional affiliations.

Received: 8 November 2018 Accepted: 6 February 2019

Published online: 18 February 2019

\section{References}

Abou El-Anwar EA (2017) Mineralogical, petrographical, geochemical, diageneses and provenance of the cretaceous black shales, Duwi formation at QuseirSafaga, Red Sea, Egypt. Egypt J Geol 26:915-926

Abou El-Anwar EA (2018) Lithologic characterization of the phosphorite bearing Duwi Formation (Campanian), South Esna, West Nile Valley, Egypt. Carbonate Evaporite. https://doi.org/10.1007/s13146-018-0442-1

Abou El-Anwar EA, Mekky HS, Abd El Rahim SH, Aita SK (2017) Mineralogical, geochemical characteristics and origin of Late Cretaceous phosphorite in Duwi formation (Geble Duwi Mine), Red Sea region, Egypt. Egypt J Petrol 26:157-169

Abou El-Anwar EA, Mekky HS, Abdel Wahab W (2018b) Geochemistry, mineralogy and depositional environment of black shales of the Duwi Formation,
Qusseir area, Red Sea coast, Egypt. Carbonate Evaporite. https://doi.org/10. 1007/s13146-017-0417-7

Abou El-Anwar EA, Samy Y (2013) Clay mineralogy and geochemical characterization of some Quaternary sediments on Giza-Fayium District, the Nile Valley, Egypt: relationships to weathering and provenance. J Appl Sci Res 9(8):4765-4780

Abou El-Anwar EA, Samy YM, Salman SA (2018a) Heavy metals hazard in Rosetta branch sediments, Egypt. J Mater Environ Sci 9(7):2142-2152

Asmoay ASA (2017) Hydrogeochemical studies on the water resources and soil characteristics in the western bank of the River Nile between Abu Qurqas and Dayr Mawas, El Minya Governorate, Egypt. PhD Thesis, AlAzhar Univ, p 255

Cartacuzencu S, Lazar I, Nedeff V, Lazar G (2014) Technical solution to reduce soil erosion produced by Tazlau river in Tarata perimeter, Romania. Environ Eng Manag J 13:1971-1978

Centeri C, Jakab G, Szabo S, Farsang A, Barta K, Szalai Z, Biro Z (2015) Comparison of particle-size analyzing laboratory methods. Environ Eng Manag J 14(5): $1125-1135$

Chein JH, Somponges D (1987) Evaluation of shortterm efficiency of diammonium phosphate versus urea plus single superphosphate on a calcareous soil. Agron J 79:896-900

Conoco, Geologic map of Egypt (1987) Egyptian general authority for petroleum. In: Scale (1:500,000), NG 36 NW Asyut

Deshmukh KK, Aher SP (2014) Particle size analysis of soils and its interpolation using GIS technique from Sangamner area, Maharashtra, India. Intern. Res J Environ Sci 3(10):32-37

Driessen PM, Deckers JL (2001) Lecture notes on the major soils of the world. World soil resources report 94. FAO, Rome

Folk L (1974) Petrology of sedimentary rocks. Hemplill, Austin, Texas, p 182

Gimtnez D, Perfect E, Rawls WJ, Pachepsky Y (1997) Fractal models for predicting soil hydraulic properties: a review. Eng Geol 48:161-183

Hassan ISS (2015) Geochemical speciation and enrichment of toxic heavy metals in Nile sediments and soils inEl-Tebbin area, Egypt. PhD Thesis, Fac Sci, Ain Shams Univ, Egypt, p 170

Hillel D (2004) Introduction to environmental soil physics. Elsevier/Acad. Press, San Diego, CA, p 494

Jensen JR (2000) Remote sensing of the environment: an earth resource perspective. Prentice Hall, New Jersey

Khalifa MA, Abu El Gar MS, Helal S, Hussein AW (2004) Depositional history of the Lower Eocene drowned carbonate platform (Drunka Formation), west of Assiut and El Minia stretch, Western Desert, Egypt. The 7Th International Conference on the Geology of the Arab World, Cairo Univ., pp 233-254

Khan GS (1984) Characterization of soils in the floodplains of Bannu Basin. Pakistan J Agric Res 5(1):51-58

Lin ZX, Harsbo K, Algren M, Qvarfort U (1998) The source and fate of Pb in the contaminated soils at the urban area of flaun in Central Sweden. Sci Total Environ 209:47-58

Loveland P (2003) Webb J. Is there a critical level of organic matter in the agricultural soils of temperate regions: a review. Soil Till Res 70:1-18

Mady AY, Shein E (2017) Comparison between particle size distribution as a predictor of pedotransfer functions using laser diffraction and sedimentation methods. Intern J Soil Sci 12(2):65-71

Miller RW, Donahue RL (1992) Soils: an introduction to soils and plant growth. Prentice-Hall, Inc., Englewood Cliffs, N.J.

Montero E (2005) Renyi dimensions analysis of soil particle-size distributions. Ecol Model 182:305-315

Netterber F (1978) Dating and correlation of calcretes and other pedocretes. Trans Geol Soc S Afr 81:379-391

Omara S (1972) Limestone dykes in the Nile Valley around Assiut, Upper Egypt. N J b Geol Paleont Stuttgart:475-483

Omer AA (1996) Geological, mineralogical and geochemical studies on the Neogene and Quaternary Nile basin deposits, Qena-Assiut stretch, Egypt. PhD thesis, Geol Dept Fac Sci Sohag, South Valley Univ, p 320

Ortega RA, Peterson GA, Westfall DG (2002) Residue accumulation and changes in soil organic matter as affected by cropping intensity in no-till dryland agroecosystems. Agron J 94:944-954

Osman HZ (1980) Geological studies on the area to the northwest of Assiut M.Sc. thesis, Fac. Sci., Assiut Univ., Assiut, Egypt, p 276

Poppe LJ, Paskevich VF, Hathaway JC, Blackwood DS (2001) A laboratory manual for X-ray powder diffraction: U.S. Geological Survey Open-File Report 01-041; Woods Hole, MA. https://doi.org/10.3133/ofr0141. 
Quiroga AR, Buschiazzo DE, Peinemann N (1998) Management discriminant properties in semiarid soils. Soil Sci 163(7):591-597

Said R (1962) The geology of Egypt. Elsevier Pub. Comp, Amesterdam, New York, p 377

Said R (1981) The geological evolution of the River Nile. Springer Verlag, New York, Heidelbeirg, Berlin, p 151

Smith JV (1961) Index to the X-ray powder file. Am Soc for testing materials, Philadelphia, p 3

Tamhan RJ, Motiramani DP, Bali TP, Donahue R (1964) Soil, their chemistry and fertility in tropical Asia. Prentice Hall of India, New Delhi

Weaver CE (1989) Clays, Muds and Shales. Elsevier, Amsterdam

WHO (1982) Micropollutants in river sediments. Euro reports and studies 61, Copenhagen

Youssef MM, Riad S, Mansour HH (1977) Surface and structural study of the area around Assiut, Egypt. Bull Fac Sci 6 Assiut Univ

\section{Submit your manuscript to a SpringerOpen ${ }^{\circ}$ journal and benefit from:}

- Convenient online submission

- Rigorous peer review

- Open access: articles freely available online

High visibility within the field

- Retaining the copyright to your article

Submit your next manuscript at $\boldsymbol{\nabla}$ springeropen.com 